\title{
RESOLVING "BESSARABIA ISSUE" FOLLOWING THE OUTCOMES OF THE FIRST WORLD WAR: HISTORIOGRAPHIC REVIEW
}

\section{Popenko Ya. V.}

\section{INTRODUCTION}

Modern period of the national state-building process probably more than in all the previous years of modern Ukrainian independence, require the society to be more attentive to the learning and understanding the events from the past. Moreover, people need this knowledge not only as background information but also for understanding their essence, taking into consideration their forerunner's experience and generating of the model of the modern development of Ukrainian state. Since even now the catchphrase, "Those who cannot remember the past are condemned to repeat it" is more than never relevant and and timely for modern Ukrainian nation".

The beginning of the 20 century formed the following tendencies of the political development of the European continent: a period "Pax Britannica" was gradually finished; existing system of the Vienna international relations were completely declining; German empire declared the beginning of the "era of world politics"; the process of delimiting of countries on military-political blocs etc .As a result, the First World War became an outcome of these tendencies. It is extremely important period for studying and rethinking, because due to its results the new geopolitical world configuration was created. Quite interesting and enlightening page of those times is a history of royal Romania and its role in Ukrainian state-building of the first quarter of the $20^{\text {th }}$ century.

At the initial stage of the new European and then a world war, Romania appeared to be virtually clutched between two military-political blocs Quadruple Alliance and Entente. In such difficult military-political situation, the Roman government, due to their own foreign policy was managed to use it for saving sovereignty, pursue their national interests and significantly even for a short time to expand state borders.

In 1919 Paris became a center of the world diplomacy because even there the conference which had to "de jure " sum up the First World War. In terms of tactical purpose, it had to work out a set of treaties with the conquered countries of the Quadruple Alliance. Strategically, it was about redistributing spheres of influence and creating a new map of Europe and the world. 
Among others, discussions and contradictions in the leadership of the conference raised questions related to the territories of the former Russian Empire where civil war was going on at the time. One of the key problems was "the Bessarabia issue" which was hoped for by several statesmen: Romania, the Ukrainian People's Republic (UNR), the governments of Generals A. Denikin and O. Kolchak, the RSFSR, the Ukrainian SSR. As a result of the open debates and arrangements, on October 28, 1920, the Paris Protocol was signed recognizing Romania's sovereignty over Bessarabia ${ }^{1}$.

The experience of "fair" solution to "Bessarabia issue" still remains of some practical and science interest. As nowadays experience confirms, the existing national borders are only notionally stable and, accordingly, due to the changing geopolitical situation in the world, they can be revised and changed in favour of the more powerful and influential players on the world political arena. This provokes the formation of new points of rivalry and conflicts and does not facilitate the establishment of a peaceful dialogue between the countries. On the other hand, the "historiographical work" on the topic also indicates the interest of scientists in its study and rethinking. The "Bessarabia issue" of 1918-1920 was evaluated, analyzed and characterized from completely diametrically opposed positions, starting with full approval and ending with unconditional condemnation.

The aim of the suggested further study is to analyze the scientific publications of the foreign and Ukrainian researchers, dedicated to the "Bessarabia issue" during the 1918-1920.

\section{The territorial affiliation of Bessarabia in the Paris Conference decision-making process in Russian-language historiography}

The first meetings of the Paris Conference confirmed the virtual rift of the team of the victorious states. France wanted to weaken the German in order to establish the hegemony in Europe and reinforce the eastern borders. However Great Britain and USA were more interested in saving of the military-political and economic equilibrium, so their representatives were more tolerant to take into account the interests of the defeated states.

The lively discussions and contradictions among the management of the conference raised questions related to the territories of the former Russian Empire. One was the "Bessarabia issue " which was favored by several stakeholders: Royal Romania (actually annexed by Bessarabia in 1918 - ed.), The UNR, the governments of the White Guard Generals A. Denikin and

\footnotetext{
${ }^{1}$ Clarification: a compromise draft of the Treaty of Bessarabia was prepared at the Paris Peace Conference on April 14, 1920. On August $10^{\text {th }}$, US diplomats refused to sign it. The remaining Allies (Great Britain, France, Italy and Japan) signed the Paris Protocol on October $28^{\text {th }}$, but it wasn't ratified by Japan. According to the international law, it didn't come into force.
} 
O. Kolchak, the RSFSR, Bulgaria. However, the latter had minimal chances, since it belonged to the defeated states of the Quadruple Alliance. As a result of the open political debate and behind-the-scenes arrangements, on October 28, 1920, the Paris Protocol (the Bessarabian Protocol) was signed, recognizing Romania's sovereignty over Bessarabia.

It should be noted that scientific publications of the foreign scientists, dedicated to "Bessarabia topic" is quite diverse. Some parts of them are dedicated to the general perspectives of this problem in the context of development of the new Versailles system of international relations, which was created on the basis of the First World War. In particular, the authors of the Russian Institute for Strategic Studies in their report stress that Bucharest began to create the Bessarabian map as early as the war of 1914-1918. According to experts, Romania has successfully implemented the chosen political strategy, its main components are:

$>$ expected international neutrality;

$>$ diplomatic maneuvering between the Entente and the Quadruple Alliance;

constant manipulation of public opinion by disseminating the idea of the need to expand state borders by joining new territories;

$>$ attempts to get political assurances from the "great powers" for the official entry of the kingdom into war, etc.

As a result, this enabled Bucharest to phase out the Greater Romania program.

In 1917, thanks to the Bolshevik coup and the actual withdrawal of the Russian Empire from World War II, Romania entered an active phase of annexation of new lands, including Bessarabia. However, the Romanian government continued to maneuver between the belligerent powers. By signing the April 24 ${ }^{\text {th }}$ (May $7^{\text {th }}$ ) 1918 Bucharest Peace Treaty with the Quadruple Alliance and having received guarantees from Germany on Bessarabia's accession to the kingdom, in November 1918 Romania returned to the Entente camp. Alongside this diplomatic turmoil, its military contingents have already occupied a number of territories - Bessarabia, Bukovina and part of Transylvania. It was then, according to Russian researchers, that the Romanian government intensified the "Bessarabia issue"." At the same time, it began to be actively used by the Romanian Foreign Office as an exclusively domestic issue in the European capitals (London and Paris) as well as in the USA.

\footnotetext{
${ }^{2}$ Хотькова Е.С., Ермаков С.М., Каширин В.Б. Румыния : истоки и современное состояние внешнеполитического позиционирования государства. Москва : РИСИ, 2013. С. 16.

${ }^{3}$ Хотькова Е.С., Ермаков С.М., Каширин В.Б. Румыния : истоки и современное состояние внешнеполитического позиционирования государства. Москва : РИСИ, 2013. С. 28.
} 
According to V. Yastrebchak, Romanian diplomacy of 1918-1920 can serve as a "model" for others. We can also agree with the author, that Romania's desire and ability to act independently when it comes to a real opportunity to become a regional leader should not be underestimated ${ }^{4}$.

The thesis of the kingdom's status as a regional leader in the Danubian region is confirmed by other researchers. In particular, V. Vinogradov notes that the foreign policy program of Bucharest during the period of the end of the First World War and in the following years was aimed at the creation of "Greate Romania". In support of his words, the author cites the words of the then Prime Minister of Romania, I. Bretian, who noted: "Romania will not allow Bulgaria's expansion too much, and the balance in the Balkans should remain the leading state" . According to the implementation of this plan, it was necessary for Bucharest to get a control over all Bessarabia. In addition to the mentioned work, V. Vinogradov's creative work is presented by other publications in which, among other issues, Bessarabian issues are analyzed ${ }^{6}$.

In addition to the general works ${ }^{7}$, dealing with "Bessarabia issue" of the first quarter of the twentieth century, there is a considerable number of publications in which the topic has been given close attention.

M. Meltyukhov's study "The Bessarabia issue Between the World Wars of $1917-1940 " 8$ focuses these aspects. By using a wide range of sources and new declassified archival materials, in this work the author analyzed both internal and external prerequisites for the occupation of Bessarabia by Romanians in 1918. In addition to it, is presents extremely important material on the history of Sfatul Tseriy (County Council) activity as a provisional elective authority on the territory of the former Bessarabia Governorate ${ }^{9}$. The researcher completely rejects the claim of some Romanian historians that the

4 Ястребчак В.В. Феномен “Великой Румынии” и румынская дипломатия в годы Первой мировой войны. Восточная политика Румынии в прошлом и настоящем (конец XIX - начало XXI вв.) : материалы международной научной конференции. (г. Тирасполь, 24-25 марта 2011 г.). Москва : РИСИ, 2011. С. 21.

${ }^{5}$ Виноградов В.Н. Румыния в годы первой мировой войны. Москва : Наука, 1969. С. 21-22.

${ }^{6}$ Виноградов В.Н. Румыния в годы первой мировой войны. Москва : Наука, 1969. С. 21-22.

7 Березняков Н.В. Борьба трудящихся Бессарабии против интервентов в 1917-1920 гг. Кишинев : Государственное издательство Молдавии, 1957. 317 с.; Большевики Молдавии и Румынского фронта в борьбе за власть Советов (март 1917 г. - январь 1918 г.). Документы и материалы. Кишинёв : Картя Молдовеняскэ, 1967. 450 с.; История дипломатии / сост. А. Лактионов. Москва : АСТ, 2009. 943 с. Лунгу В.Н. Политика террора и грабежа в Бессарабии 1918-1920 гг. Кишинев : Картя Молдовеняскэ, 1979. 216 с.; Нотович Ф.И. Бухарестский мир 1918 г. Москва : Изд-во социально-экономической литературы, 1959. 258 с.

8 Мельтюхов М.И. Бессарабский вопрос между мировыми войнами 1917-1940. Москва : Вече, 2010. 464 с.

9 Мельтюхов М.И. Бессарабский вопрос между мировыми войнами 1917-1940. Москва : Вече, 2010. С. 21-26. 
representatives of Sfatul Tseriy unanimously and voluntarily declared the need to annex the region exclusively to Romania.

Basing upon archival documents, M. Meltyukhov emphasizes that the situation during 1918-1919 was not as straightforward as Romanian historians have argued. Thus, in the Bessarabia government, there were completely opposite views on the future legal status of the region:

$>$ some spoke in favor of joining Romania;

$>$ others argued for the existence of the People's Republic of Moldova (proclaimed December 2 (15), 1917);

$>$ others sought its accession to the Ukrainian People's Republic;

$>$ some were willing to enter the Great Russian Federal Democratic Republic.

$>$ some of the delegates supported the idea of an alliance with the Bolsheviks.

According to the author's opinion, only the permission of the Quadruple Alliance (in 1918) was granted at first, and subsequently the Entente (1919) gave Romania the opportunity to occupy Bessarabia and legally consolidate it in $1920^{10}$.

Among the monographs dedicated to the Bessarabia issue in the chronological period that have recently been released, the publication that's woth mentioning is "Bessarabia issue in the context of international relations (1919-1920) Paris Peace Conference"11 by the Moldovan historian I. Levit. In his work, the author analyzed how and in what way the Bessarabia issue arose and was formalized, as it was perceived not only by Romanian governmental circles, but also by European and American diplomacy.

In the study I. Levitt proposed three main chronological stages of the existence and development of the "Bessarabia issue":

$>$ the first one was 1917-1918, when in the conditions of the First World War and the Civil War in the territory of the former Russian Empire it finally formed in the governmental circles of Bucharest and gradually began to enter the international diplomatic arena;

$>$ the second - in 1919, when the "Bessarabia issue" was directly resolved at the level of the Paris Peace Conference;

$>$ the third is 1920, when Bessarabia international legal status was enshrined in the notorious Paris Protocol.

It should be noted that the author had to analyze an extremely large amount of information related to the topic to maintain the principle of

10 Мельтюхов М.И. Бессарабский вопрос между мировыми войнами 1917-1940. Москва : Вече, 2010. С. 28.

11 Левит И.Э. Бессарабский вопрос в контексте международных отношений (1919-1920 гг.). Парижская мирная конференция. Тирасполь : Литера, 2012. 240 с. 
historical objectivity. In particular, I. Levitt analyzes not only the "Romanian" vision of the problem in the interpretation of politicians and diplomats of the time (I. Bretian, T. Ionescu, V. Antonescu, K. Diamandi, A. Averescu, etc.), but also the attitude to him by other states. For example, how the Bessarabian issues were perceived and evaluated by representatives of France (J. Clemenceau and S. Pichon), the United Kingdom (A. Balfour and D. Lloyd George), the United States (C. Vopichka, F. Polk and R. Lansing) and others Outside of the researcher's attention, the media of the time were not left behind. In order to confirm or refute his own thoughts, I. Levitt quotes the press of the time, in particular, the publications "Le Temps", "Excelsior", "L’Humanité", "Izvestiya CEC", "Odessa listok", etc.

For the purpose of objective research and presentation of his own positions, the author cites the material of archives and official collections of documents of the respective states (in particular, "Papers Relating to the Foreign Relations of the United States. The Paris Peace Conference. 1919", "Documents on British Foreign Policy 1919-1939 "Documents of Foreign Policy of the USSR").

The military-political situation around the territorial affiliation of Bessarabia was also reflected in the works of S. Nazaria ${ }^{12}$. In particular, in the article "Rakovsky - Averescu Agreement" ".. the author covered the course of events related to the agreement of March 5-9, 1918. In the context of the agreement signed between the parties, the author analyzed the complex negotiation process between Romania, the Quadruple Alliance, the Entente which eventually ended with the military annexation of the Ukrainian territories of Bukovina and Bessarabia. According to the researcher, the new Romanian government, formed by General A. Averescu on February 5, 1918, was "to delay negotiations with the Germans and give the Entente the

12 Назария С. “...Сможем быстро захватить Бессарабию. Начало румынской антисоветской интервенции в оценках современных историков”. Свободная мыслль. 2013. URL: http://www.svom.info/entry/337-smozhem-bystro-zahvatit-bessarabiyu/?collection=22 (дата обращения 17.06.2018); Назария С. Позиция Западных держав в бессарабском вопросе на Парижской мирной конференции. URL: https://ava.md/2014/01/21/poziciyazapadnyh-derzhav-v-bessarabskom/ (дата обращения: 8.06.2018); Назария C.М. Появление Бессарабского вопроса на последнем этапе Первой мировой войны и интерпретация этих событий в исторической и мемуарной литературе. Русин. 2014. № 4 (38). С. 61-78.; Назария С.М. Соглашение "Раковский - Авереску" от 5-9 марта 1918 г. об очищении Бессарабии румынской администрацией и войсками и его интерпретации в современной историографии. Alipirea Basarabiei la Rusia în contextul relaţiilor multiseculare moldo-rusoисrainene / "Присоединение Бессарабии к России в свете многовекового молдо-российскоукраинского сотрудничества". Chişinău, 2012. С. 130-135; Назария С.М. Соглашение Раковского - Авереску от 5-9 марта 1918 г. в историографии и мемуарах румынских политиков. Проблемы национальной стратегии. 2014. № 2 (23). С. 155-165. 
impression of the" inevitability "of the signing of a separate peace by Romania" $"$.

At the same time, it should be noted that the researcher, in their coverage of the events, completely ignores all measures taken by the Ukrainian national governments to return the territories illegally occupied by the Romanian Kingdom. Although he stated that "the most difficult thing for Romania happened: it was necessary to provide the annexation of the region with at least the appearance of "legality" terms of international law"14.

In the the researcher states that during the 1918-1920's the "Bessarabia issue" reflected the conflicts of interest of different international actors and different vectors of international relations, namely:

$>$ the camp aimed at fighting the world communist revolution;

$>$ supporters of the idea of forming a "sanitary border" against the penetration of Bolshevism in the West;

$>$ geopolitical aspirations of the leading Western powers to obtain a convenient bridgehead for ousting Russia (with any government - the author) to the east and gaining full control of the Danube mouth;

$>$ Bucharest's immediate plans to create a Greater Romania;

$>$ the desire of the great powers to conquer Romania in the interests of the victorious states in the First World War ${ }^{15}$.

Aspects of international law related to the annexation of Romania to the Bessarabian lands were analyzed in their work by V. Makarchuk and N. Rudy. Citing a number of international agreements (in particular, the treaty between Romania and the Entente of August 4, 1916) and from the point of view of international law in force at the time, the authors stated that "the Romanian occupation of Bessarabia could not be legitimized by either the Sfatum Cerai Initiative or the decision. conferences on the transfer of the Romanian region" ${ }^{" 16}$ Like S. Nazarius, the authors also ignored the fact that Ukrainian

${ }^{13}$ Назария С.М. Соглашение "Раковский - Авереску” от 5-9 марта 1918 г. об очищении Бессарабии румынской администрацией и войсками и его интерпретации в современной историографии. Alipirea Basarabiei la Rusia în contextul relatiilor multiseculare moldo-rusoисrаinепе / "Присоединение Бессарабии к России в свете многовекового молдо-российскоукраинского сотрудничества”. Chişinău, 2012. C. 131.

14 Назария С.М. Соглашение Раковского - Авереску от 5-9 марта 1918 г. в историографии и мемуарах румынских политиков. Проблемы начиональной стратегии. 2014. № 2 (23). С. 164.

15 Назария С. “... Сможем быстро захватить Бессарабию. Начало румынской антисоветской интервенции в оценках современных историков”. Свободная мыслль. 2013. URL: http://www.svom.info/entry/337-smozhem-bystro-zahvatit-bessarabiyu/?collection=22 (дата обращения 17.06.2018).

${ }^{16}$ Макарчук В., Рудый Н. Восточные границы межвоенной Румынии (1918-1940 гг.) : аспекты международного права. Русин. 2012. № 2 (28). С. 64. 
national governments existed, and analyzed all the negotiations that took place around Bessarabia at the level of the Romania-RSFSR-USRR intergovernmental dialogue.

In a similar interpretation of historical events, the Bessarabian issue was presented by Moldovan researcher P. Boyko. By his definition, the problem of Bessarabia during the late 1918-1920ss is a conventional symbol of interstate relations between Soviet Russia (later the USSR) and royal Romania, caused by the occupation of Soviet territory, carried out by Romanian ruling circles in 1818 in world war conditions ${ }^{17}$. Of course, this is not the immediate objective of this publication, but it will not be superfluous to note that the author of the previous citation in some way ignores the following aspects:

$>$ Firstly, in 1918 only a few were in force in Ukraine governments: the UPR of the Central Council and the Ukrainian State of P. Skoropadsky;

$>$ Secondly, the definition of "Soviet territory" in relation to 1918 certain reservations since the USSR was formally established on December 30, 1922 at the First Congress of Soviets, where delegates from the RSFSR, the USSR, the BSSR and the Caucasus The SFRD reviewed and approved the draft Declaration and Treaty of formation USSR;

$>$ Thirdly, the diplomatic struggle for Bessarabia was led by representatives Russian White Guard movement. For example, no question aside representatives of the Kolchak government remained. The leadership of the Paris conferences in 1919-1920 repeatedly received memoranda from G. Lvov, S. Sazonov, M. Tchaikovsky, V. Maklakov about groundlessness Romanian claims on the region. Moreover, there were Russian Political Meeting and Russian Political Delegation in Paris ${ }^{18}$. It is the representatives the white movement told in Paris about the necessity to hold in Bessarabia is a local plebiscite, which should finally define the state-political status of the region. By the way, V. Maklakov's position on necessity The referendum was supported by US representatives R. Lansing and F. Polk.

This issue is more carefully and objectively reflected in publications of Russian historians I. Barinov and I. Strelkov "The Western Frontier in Ukrainian and Russian representation..."19. They also highlighted the individual issues related to the Ukrainian-Romanian confrontation around the territories Bukovina and Bessarabia during the Paris Conference. In particular, the researchers noted that all activities and appeals to the UNR government to

17 Бойко П. Бессарабский вопрос по итогам Первой мировой войны. Русин. 2014. № 4 (38). C. 48.

${ }^{18}$ Цветков В.Ж. Белое дело в России. 1919 г. (формирование и эволюция политических структур Белого движения в России). Москва, 2009. С. 374.

19 Баринов И., Стрелков И. Западная граница в украинском и русском представлении: между пропагандой и политикой (1914-1919 гг.). Русин. 2013. № 1 (31). С. 78-94. 
the leadership the Bessarabia peace conference has never been considered in favor of the Ukrainian side. Instead, the Romanian government considered it official inhabitants of the region (Moldovans, Ukrainians, Russians and others) exclusively "Romanian citizens who have forgotten their native language" 20 .

Issues related to the situation around Bessarabia in the context of the interstate relations of the European states at the end of the First D. Maltsev also analyzed in his publication World $\mathrm{War}^{21}$. He stated that that it became particularly acute after the revolutionary events in Russia, which caused the rise of disintegration processes and the rise of national liberation struggle in the territories of the former Romanov Empire. Author stressed that all territorial claims of Romania on the former Bessarabia the province had no real basis. In particular, D. Maltsev emphasized attention to the fact that Bessarabia remained aloof from the formation processes the newest Romanian statehood. Most Moldovans who populated the region never considered themselves Romanians. The land's annexation to the kingdom has taken place contrary to the position of the local public. Moreover, the referendum on which the Entente leaders insisted, and there were no Kolchak government representatives supported by the Romanian side (this fact is confirmed by the official ones) documents of that time). Occupying Bessarabia, Romanian civilian and military administration resorted to the physical extermination of the local population. This fact also finds confirmation in both the official documents of the time and the latest scientific research ${ }^{22}$.

\section{Conclusions}

To sum it up, the expansionist policy of Romania, formed from the postulates of "Greater Romania", was to justify territorial claims on a number of lands, in particular Bessarabia, in the context of existing international relations. Moreover, the seizure of these lands was considered by the Romanian authorities to be a natural result of the Kingdom's participation in World War I on the side of the victorious Entente.

It is a difficult task to put all the historiographical work on the topic within the limits of a separate publication, so the emphasis was placed on the works of Russian-speaking researchers. On the whole, we can say that the "

${ }^{20}$ Баринов И., Стрелков И. Будущее Буковины в контексте русских, украинских и румынских предложений на Парижской мирной конференции 1919 г. Русин. 2012. № 2 (28). C. 38 .

${ }^{21}$ Баринов И., Стрелков И. Будущее Буковины в контексте русских, украинских и румынских предложений на Парижской мирной конференции 1919 г. Русин. 2012. № 2 (28). C. 38 .

${ }^{22}$ Суляк С. Русины в период Первой мировой войны и русской смуты. Русин. 2006. № 1 (3). C. 55-58. 
Bessarabia issue" was reflected in the writings of modern historians, but needs further research, since the "Balkan issue" during 1918-1920 was one of the most difficult in the context of the nascent Versailles system of international relations.

\section{The "Bessarabia issue" and Romanian Direction of Ukrainian Diplomacy in Recent National Historiography}

The Ukrainian national liberation competitions of the first quarter of the twentieth century are an extremely important, complex and eventful period in the history of interstate relations between Ukraine and Romania. During the relatively short time of the first quarter of the twentieth century, the form and essence of statehood changed several times in Ukraine. At the end of April 1918, the conservative leadership of the Ukrainian State of Hetman P. Skoropadsky came to replace the revolutionary-socialist government of the First UNR. In December 1918, he also "descended" from the historic arena, giving way to the Second UNR Government of the Directory. In Western Ukraine, the state-making movement was also able to realize itself in the form of a democratic ZUNR government. It was during these turbulent years that both Ukraine and Romania jointly attempted to establish and establish interstate relations.

In general, the history of Ukrainian-Romanian relations was full of important events for both countries during the period. However, most of them have recently been considered by historians rather tendently, which did not allow, in accordance with the principles of objectivity, to cover the complex process of relations between states, especially in the context of the " Bessarabia issue". Only the cardinal political changes that took place in the world at the end of the twentieth century. were able to make things better. The entry of a sovereign Ukraine into the political arena, proclaiming it a EuroAtlantic foreign policy course, has allowed modern researchers to "review" the historical stereotypes that formed in the enlightened relations between the states during the tumultuous times of the Ukrainian national liberation contests of the first quarter of the 20 century.

On the other hand, Romania, which has been a NATO member since March 2004 and the European Union since January 2007, is trying to change its attitude towards the ambiguous history of relations with Ukraine. Obviously, right now between the states there are quite favorable conditions for the scientific study and rethinking of many aspects of the common history of the first quarter of the twentieth century.

After all, we can say with confidence that research and an objective analysis of the topic will enable us to fully disclose the little-known pages of our common history through the lens of modern pan-European integration 
processes. This will avoid the mistakes of the past in forming the principles of mutually beneficial relations between Ukraine and Romania at the present stage of interstate relations. Moreover, right now, according to historian V. Kreutor, "favorable conditions are being created for the scientific and comprehensive coverage of many aspects of this problem" 23 .

It should be noted that scientific publications analyzing interstate diplomatic, socio-economic, military, etc. aspects of Ukrainian-Romanian relations are quite diverse. Some of them are devoted to the general tendencies of development of relations between the countries in the context of the formation of a new European system of interstate relations, which was actively created and developed at the end of the First World War. And if Romania, as an ally in the military coalition of the Entente countries, managed to remain an integrated part of the European political and economic community, Ukraine lost that opportunity for some historical time. Among the works we should mention the research of V. Boechko ${ }^{24}$, M. Derzhalyuk ${ }^{25}$, O. Pavlyuk ${ }^{26}$ and others.

Significant Volume of the factual material on the history of UkrainianRomanian relations is presented in the thematic collection of scientific articles, which was based on the results of the International Scientific Conference held in Chernivtsi in $2001^{27}$. The following articles deserve special attention in this collection:

Goshuliak, in which the author analyzed the course of events in the direction of solving the "Bessarabian" issue "during the government of the First UNR;

$>$ The Romanian factor and its direct influence on the establishment of Ukrainian statehood in 1918 were covered by T. Bevz and V. Yaremchuk;

$>\mathrm{O}$. Lyubovets presented the analysis of the positions of Ukrainian political parties regarding the historical affiliation of Bukovina and Bessarabia with Ukraine;

$>$ Poddubny described the course of diplomatic relations between Ukraine and the Kingdom of Romania during 1918-1923.

${ }^{23}$ Кройтор В. Українське питання в політиці Румунії (1918-1927рр.) : історіографічний контент. Вісник Прикарпатського університету. Вип. 23-24: До 20-ліття утворення кафедри історії слов'ян і 80-річчя професора Петра Федорчака. С. 281.

24 Боєчко В., Ганжа О., Захарчук Б. Кордони України : історична ретроспектива та сучасний стан. Київ: Основи, 1999. 168 с.

25 Держалюк М.С. Міжнародне становище України та іiі визвольна боротьба у 1917-1922 роках. Київ: Оріяни, 1998. 240 с.

${ }^{26}$ Павлюк О. Зовнішня політика ЗУНР. Київька старовина. 1997. № 3-4. С. 114-138.

27 Україна - Румунія - Молдова : історичні та культурні аспекти взаємин : Матеріали міжнародної наукової конференції (16-17 травня 2001 р.). Чернівці : Букрек, 2002. 512 с. 
Summarizing their work, national scientists confirmed the fact that during the Ukrainian national liberation competitions of the first quarter of the twentieth century. Romania has been an important strategic political and economic partner of Ukraine throughout the Black Sea and Balkan regions. At the same time, it should be noted that the more "saturated" scientific publications of contemporaries on the history of Ukrainian-Romanian interstate relations of the 1917-1920's are still the period of the Second UPR (the end of 1918-1921).

Among the studies that analyze the course of relations between Ukraine and the Kingdom of Romania during the days of the Central Council and Hetmanate P. Skoropadsky, one should single out the publication of P. Satsky. In his work, the author raises one of the most difficult issues in the relationship between Ukrainians and Romanians of the time - the signing of the Russian-Romanian treaty on March 5-9, 1918 on the state-legal status of Bessarabia and defining its historical knowledge defining its historical significance. According to the author, it is the objective study of the Bessarabia issue that will help to understand the specifics of interstate relations in Central Europe and the Balkan Peninsula and, most importantly, determine their place in Ukraine. The author cannot but agree that it was the military annexation of the historical Ukrainian territories by the Romanian troops that began the confrontation between the countries. On the other hand, it is quite correct to state that "with the changing situation in the former Russian Empire and the international status of Russia initiated by the Bolshevik government, it was important for Romania to confirm its allied relations with the Entente countries" 28 .

It should be emphasized that if in the times of the Government of the Central Rada - the conflict had a more "paper" format (notes, appeals, memoranda other purely diplomatic steps), then the next government of P. Skoropadsky brought it into a more effective plane - economic. The numerical advantage of the Ukrainians, the economically advantageous location of the territory in the direction of establishing economic cooperation with other countries of the Balkan region, according to P. Satsky, "gave reason to the Ukrainian state to actively intervene in the affairs of this province, considering the territorial disputes between Ukraine and Romania",29.

28 Сацький П.В. Українсько-румунські прикордонні відносини наприкінці 1917 у 1918 рр. і роль російсько-румунського договору 5-9 березня 1918 р. Збірник наукових прачь Науково-дослідного інституту украйнознавства. 2007. Т. 15. С. 442.

29 Сацький П.В. Українсько-румунські прикордонні відносини наприкінці 1917 у 1918 рр. і роль російсько-румунського договору 5-9 березня 1918 р. Збірник наукових праць Науково-дослідного інституту украӥнознавства. 2007. Т. 15. С. 449. 
Issues related to the situation around the Ukrainian territories of Bessarabia (and Bukovina - Ed.) In the context of the interstate relations of European states at the end of World War I were also analyzed by S. Hakman in his works ${ }^{30}$. He stated that they gained special tension between the parties after the revolutionary events in Russia, which caused the increase of disintegration processes and the rise of national liberation struggle in the territories of the former empire ${ }^{31}$.

Separately in his publications, the author also analyzed the course of the diplomatic struggle for these lands during the Paris Conference. In particular, the researcher noted that the main problem of royal Romania in determining the international status of the Danube territories was the position of US representatives, who argued that the designated lands of the Romanian population did not represent a dominant majority. Moreover, before the outbreak of World War I, Bessarabia was generally part of the Romanov empire, which had never been in a state of military conflict with the kingdom. According to these considerations, US diplomats did not consider it appropriate to transfer these territories to the exclusive Romanian jurisdiction. But based on geopolitical considerations, fearing that the ideas of Bolshevism would spread further to the European continent and in connection with the military defeat of the UNR government, the Entente leaders ultimately adopted a positive decision for Romania. For example, on September 10, 1919, under the Saint-Germain Peace Treaty, Austria relinquished its claim to Bukovina in favor of Romania. The new borders of the kingdom were finally fixed by the Treaty of Sevres of August 10, 1920. Soon, on October 28, 1920, according to the Paris Protocol, Entente leaders signed an agreement to annex Bessarabia to Romania - the position of Ukrainian representatives was not taken into account, since he was in fact in exile.

In their article S. Appatov and I. Makan also state that the period of revolutionary changes in the territories of the former Russian Empire "constitutes a special stage in the Ukrainian-Romanian relations" 32 . Yes, indeed the Kingdom of Romania was one of the first to recognize the Ukrainian government as "de facto". Moreover, quite promising trade and

30 Гакман С. Проблема Буковини на Паризькій мирній конференції 1919-1920 pp. Питання історї̈ нового та новітнього часу. 2000. Вип. 7. С. 163-174; Гакман С. Буковина у політиці Росії, України та Угорщини навесні 1919 р. Науковий вісник Волинського державного університету імені Лесі Украӥнки : Історичні науки. 2000. № 3. С. 139-143.

${ }^{31}$ Гакман С.М. Проблема Бессарабії та Буковини у контексті радянсько-румунських міждержавних відносин. 1917-1940 р.p. : автореф. дис. ... канд. іст. наук : 07.00.02. Чернівці, 2001. С. 5.

32 Аппатов С.Й., Макан І.М. Українсько-румунські відносини : історія та сучасність. Украӥнський історичний журнал. 1999. № 5. С. 91. 
economic cooperation was opened between the states. At the same time, like previous authors, the researchers state that the annexation of the Romanians of Bessarabia and Northern Bukovina has become a barrier to establishing good relations. The authors stress the attempts of the Ukrainian governments to return these territories to the jurisdiction of Kyiv, but in the end, they all failed. At the same time, if P. Skoropadsky's government emphasized that "Ukraine has all the rights to this territory and the vast majority of its population wants it" 33 , the government of the UNR Directory, through its military-political and economic weakness, tried not to complicate relations with the kingdom (in fact, it refused). from these lands.

Of course, the fact that behind Romania in the Bessarabia issue there was an Entente that did not recognize Ukrainian sovereignty cannot be overlooked. This was clearly demonstrated by the final decisions of the Paris Peace Conference. On the other hand, it is not worth saying that the Entente carelessly supported Romania. In particular, only in 1924 did France finally ratify the Bessarabian Accords.

V. Lozov's research is also devoted to relations between the UNR and the Kingdom of Romania. The author focused on relations between the parties during the so-called "Kamyanets" period of the Directory Government. In addition to the political format of the negotiations, the paper also analyzes the process of establishing trade and economic relations between the parties. According to V. Lozov, establishing full-fledged contacts was mutually beneficial for both countries. According to him, "the Romanian government, especially the military circles military circles, tried to keep in touch with the leadership of the $\mathrm{UNR}^{34}$. One can not disagree with the conclusion of a researcher who claims that in the Kamyanets era the kingdom became one of the main directions of the diplomatic activity of the UNR. V. Lozov's conclusion in some way refutes the stereotype that there was no independent "Ukrainian" issue in European politics during the formation of the Versailles system of international relations at all. It existed, moreover, to some extent or another, the states of the European continent often met with it when forming a new map of postwar Europe.

Military aspects of cooperation between Ukraine and Romania in 1919 dedicated to M. Kovalchuk's publication. In the study, based on archival documents and memoirs, the author analyzed the thorny path of establishing Ukrainian-Romanian military cooperation.

33 Аппатов С.Й., Макан I.М. Українсько-румунські відносини : історія та сучасність. Украӥнський історичний журнал. 1999. № 5. С. 92.

34 Лозовий В. Відносини Української Народної Республіки з Румунією у Кам'янецьку добу Директорії УНР. Проблеми історї країн Центральної та Східної Свропи: збірник наукових праць. 2011. Вип. 2. С. 136. 
Like previous researchers, M. Kovalchuk also confirms the thesis that the emergence of an independent Ukrainian state has caused mixed reactions from the Romanian side. On the one hand, Romania had to adhere to the position of the Entente leaders in support of the idea of reviving the "one and indivisible Russia", but on the other, the very existence of Ukraine could have protected Romania from the spread of Bolshevism. At the same time, most Romanian leaders understood that sovereign Ukraine would sooner or later "raise" territorial claims against Romania regarding the occupation of the latter by Bessarabia and Bukovina.

Thus, according to M. Kovalchuk, it was "the threat of territorial contradictions, as well as the non-recognition of Ukraine by the Entente States that hindered the establishment of diplomatic relations between Bucharest and Kiev" 35 . In addition, it should be remembered that during the interwar period, the political project of Greater Romania, which in fact envisaged the expansion of the country's borders at the expense of its neighbors, was extremely popular and state-supported in the Romanian environment.

Speaking about the current state of research of these problems, one cannot ignore the scientific achievements of V. Kreutor ${ }^{36}$. For the first time in national historical science, the author conducted a comprehensive study of the "Ukrainian issue" in Romanian politics during 1918-1927. conditions of existing international relations. Moreover, the seizure of these lands was considered by the Romanian authorities to be the natural result of the country's "participation" in World War I.

A number of publications on the diplomatic struggle for the legal status of Bessarabia, especially in the context of the Paris Peace Conference, have also been published by the author of a collective monograph proposed to readers ${ }^{37}$.

35 Ковальчук М.А. Відносини Румунії з урядом Української Народної Республіки в 1919 р. Украӥнський історичний журнал. 2010. № 4. С. 116.

${ }^{36}$ Кройтор В. Міжнародні чинники української проблеми в політиці Румунії на початку 20-х років XX ст. Вісник Прикарпатського університету. 2001. Випуск IV-V. С. 90-95; Кройтор В. Політика національної асиміляції українців у Румунії на початку 20 -х років XX ст. Галичина. Науковий і культурно-просвітній краєзнавчий часопис. 2001. № 7. С. 163-169. Кройтор В. Хотинське національно-визвольне повстання 1919 р. Історія в школі. 2001. № 5. С.7-11; Кройтор В. Проблема Покуття у відносинах між Румунією і ЗУНР. Галичина. Науковий $і$ культурно-просвітній краєзнавчий часопис. 2001. № 5-6. С. 231-234; Кройтор В. Бессарабська проблема в українсько-румунських політичних відносинах 1917-1918 pp. Iсторія в школі. 2001. № 1. С. 4-8; Кройтор В., Томин Ю. Український інтеграційний рух у національній політиці Румунського королівства (1918-1927рр.). Украӥна соборна. Збірник наукових статей. 2005. Вип. 2. С. 161-174; Кройтор В.К. Українське питання в політиці Румунії (1918-1927 рр.) : автореф. дис. ... канд. іст. наук : 07.00.02. Одеса, 2007. 20 с.

${ }^{37}$ Попенко Я.В. Румунська дипломатія в боротьбі за Бессарабію на Паризькій мирній конференції (січень - серпень 1919 р.). Русин. Международный исторический журнал. 2018. T. 53. Вып. 3. Кишинев, Молдова. С. 152-171. DOI: 10.17223/18572685/53/9; Попенко Я. 
The author also analyzes the stories related to the difficult path of royal Romania during the First World War and the official ideology of the creation of Greater Romania by the official Bucharest ${ }^{38}$. In a joint scientific article with Professor I. Srebnyak, the purely military-diplomatic moments of relations between Ukraine and Romania were reflected ${ }^{39}$.

Actually, speaking of the current state of study of the history of the development of Ukrainian-Romanian interstate relations during the revolutionary events of the first quarter of the twentieth century, one should not overlook the scientific publications of archeographic character. For example, the opening of former special funds, intensification of the search activity of modern domestic scientists contribute to the publication of new or little-known archival documents that present the activities of the Ukrainian emergency diplomatic mission in Romania, in particular, the letters of K. Matsievich and others have seen the world ${ }^{40}$.

It should be said about the publications that analyzed and characterized the activities of the UNR diplomatic mission in Romania, K. Macijevic, who held this position during 1919-1923. In addition to his direct duties, he was one of

Румунська дипломатія у боротьбі за Бессарабію на Паризькій мирній конференції (січень травень 1919 р.). Київські історичні студї: науковий журнал. № 2(5). Київ: Київський університет ім. Б. Гринченка, 2017. С. 10-17; Попенко Я. Політична боротьба за Бессарабію на Паризькій мирній конференції упродовж травня - серпня 1919 р. Емінак : науковий щцоквартальник. 2018. № 1 (21) січень - березень. Т. 2. С. 36-41; Попенко Я. "Бессарабське питання" на Паризькій мирній конференції (осінь-зима 1919р.). Схід. Аналітичноінформаційний журнал. Серія: Історичні науки. № 4 (156) липень - серпень. 2018. С. 56-60 DOI: https://doi.org/10.21847/1728-9343.2018.4(156).140985; Попенко Я. "Я не хочу тут згадувати минуле. Моя роль - зайнятися сьогоденням та дивитися у майбутнє”: діяльність А. Вайди-Воєводи на Паризькій конференції (грудень 1919 р. - березень 1920 р.). Свропейські історичні студії: науковий журнал. № 12. Київ, 2019. С. 136-155.

38 Попенко Я. Румунія на шляху до Бухарестського миру 1918 року. Емінак: науковий щзоквартальник. 2016. № 3 (15.). Т. 2. С. 53-59; Попенко Я.В. Реалізація ідеї створення “Великої Румунії” у зовнішньополітичній діяльності Бухаресту впродовж першої чверті ХХ ст. Наукові записки Вінницького держсавного педагогічного університету імені Михайла Коиюбинського. Серія: Історія. Вип. 25. Вінниця: ФОП Корзун Д.Ю, 2017. С. 275-280.

39 Срібняк І.В., Попенко Я.В. Діяльність військового відділу Надзвичайної дипломатичної місії УНР у Румунії, 1920 р. (за матеріалами САW). Русин. Международный исторический журнал. 2019. № 57. Кишинев, Молдова. С. 157-178. DOI: $10.17223 / 18572685 / 57 / 10$.

${ }^{40}$ Власенко В. Документи і матеріали надзвичайної дипломатичної місії УНР в Румунії (1919-1923 рр.). Пам'ятки : археографічний щорічник. 2008. Т. 8. С. 129-160; Листи Костя Мацієвича до Симона Петлюри (1920-1923 рр.) / упорядкув., вст. ст. та ком. В. Власенко. Суми : ФОП Наталуха А.С., 2009. 128 с.; Власенко В. Невідомі листи Костя Мацієвича до Симона Петлюри 1920 р. Пам'ятки : археографічний щорічник. 2009. Т. 9. С. 83-110; Єпик Л.І. Листи І. Мазепи до К. Мацієвича (1919-1920рр.). Сумський історико-архівний журнал. 2012. № . XVIII-XIX. C. 12-17. 
the few Ukrainian diplomats who actively cooperated the Romanian media, using them to spread a positive image for Ukraine to the European public.

According to the researcher L. Epic, being the head of the Ukrainian Embassy in Romania, in his activities K. Maciyevich "adhered to the basic principle of his life and work - to ensure above all the private interests of individuals, whatever they impatiently would be, but to satisfy the minimum the needs of the institution and public affairs entrusted to me by the Government ${ }^{41}$ ".

\section{CONCLUSIONS}

As a conclusion, we can state, that even though the issue of UkrainianRomanian interstate relations during the first quarter of the twentieth century has received partial scholarly coverage in the papers by contemporary Ukrainian historians, it still needs further study, since the "Balkan direction" of Ukrainian diplomacy during the years of national liberation competitions has not been sufficiently described. Moreover, the complex relations between Ukraine and Romania around the "Bessarabian issue" still require further research and rethinking.

\section{SUMMARY}

The purpose of the publication is to analyze the Ukrainian-speaking and Russian-speaking historiographical heritage, devoted to the problem of determining the state-political status of Bessarabia following the results of the First World War. The tasks of the publication are to characterize the scientific achievements of national and foreign historians in describing the course of events around the decision-making regarding the territorial identity of the Bessarabian region during the formation of the Versailles system of international relations.

Due to the considerable amount of material, the author referes to only a few publications on the proposed topic, as they clearly show in what tense atmosphere a new map of postwar Europe was formed.

\section{Information about the author:} Popenko Y. V.,

Candidate of Historical Sciences, Associate Professor, Melitopol Bogdan Khmelnytsky State Pedagogical University 20, Hetmanskaya str., Melitopol, Zaporizhzhya region, 72312, Ukraine

41 Єпик Л.І. К.А. Мацієвич - науковець, дипломат, громадсько-політичний діяч. Украӥнський історичний журнал. 2007. № 1. С. 125-135. 